\title{
Effect of different industrial and domestic effluents on growth, yield, and heavy metal accumulation in Turnip (Brassica rapa L.)
}

\author{
Noor ul Ain ${ }^{1}$, Qurat ul Ain², Sadaf Javeria ${ }^{1}$, Sana Ashiq ${ }^{2}$, Kanwal Ashiq ${ }^{3 *}$, Muhammad Sufyan Akhtar ${ }^{2}$ \\ ${ }^{1}$ Department of Food Science and Technology, Faculty of Agriculture, Gomal University, D.I.Khan, Pakistan \\ ${ }^{2}$ Sharif Medical and Dental College, Raiwind Road, Lahore, Pakistan \\ ${ }^{3}$ Faculty of Pharmaceutical Sciences, Superior University, Lahore, Pakistan
}

\begin{tabular}{l}
\hline ARTICLE INFO \\
\hline Article history: \\
Received on: June 16, 2019 \\
Accepted on: July 27, 2019 \\
Available online: September 10, 2019 \\
\hline Key words: \\
Brassica rapa, effluents, heavy \\
metals, plant growth, turnip, yield
\end{tabular}

\begin{abstract}
In the suburbs of big cities, the vegetables are commonly irrigated with effluents due to paucity of good quality water. These effluents are loaded with toxic or heavy metals which may cause environmental or health hazard. The present study was performed in pot experiments to investigate the impacts of different effluents on the growth, yield, and heavy metals concentration of turnip (Brassica rapa). Pots were arranged in a completely randomized design with six treatments replicated four times. The treatments included $10 \%$ effluents of sugar mill, sewage water, soap factory, ghee mill, slaughterhouse, and control. Data on the weight of root plant $^{-1}(\mathrm{~g})$, root length, root diameter, yield ha ${ }^{-1}$, and heavy metals ( $\mathrm{Fe}, \mathrm{Pb}, \mathrm{Zn}, \mathrm{Ni}$, and $\mathrm{Cd}$ ) concentrations in roots were recorded and analyzed statistically. Results revealed that higher yield and related traits were recorded with sewage water followed by slaughterhouse wastage and sugar mill effluent. Application of sewage water enhanced $11.2 \%$ yield while the increment with slaughterhouse wastage and sugar mill effluent was $7.8 \%$ and $2.3 \%$, respectively. Heavy metal concentrations were increased with all types of effluents. The transfer factors showed that accumulation of metals was in the order of $\mathrm{Pb}>\mathrm{Cd}>\mathrm{Zn}>\mathrm{Fe}>\mathrm{Ni}$.
\end{abstract}

\section{INTRODUCTION}

Turnip (Brassica rapa L.) belonging to the Cruciferae family is a root vegetable commonly grown in temperate climates. It was a well-established crop in Hellenistic and Roman times, which leads to the assumption that it was brought into cultivation as early as 7 th century BC. Records also show that turnips are native to Asia and Eurasia [1]. It is a common edible plant around the world with lots of health benefits [2]. Accelerated urbanization and improved living standard have resulted in the generation of huge amounts of effluents and their disposal is of great concern. Moreover, the shortage of good quality groundwater for agriculture purpose has compelled the agriculturist to utilize these wastewaters [3]. The wastewaters contain an adequate amount of nutrients required for plant growth but are also loaded with a significant quantity of heavy metals which are toxic to plants and human beings. The chemical composition and characteristics of wastewaters differ

\footnotetext{
*Corresponding Author

Kanwal Ashiq, Faculty of Pharmaceutical Sciences, Superior University, Lahore, Pakistan. E-mail: kanwal.ashiq@superior.edu.pk
}

due to the source of generation like industrial and agricultural activities and population density, etc., which exert a positive or negative impact on plant growth [4]. There is scientific evidence that growth and yields of various crops can be improved with the use of wastewater [5]. Further, it was revealed that the application of wastewater induced pollution stress that reduced fresh seedling weight [6] and also have a negative effect on the growth of crops at higher concentrations [7]. Root crops such as potato, carrot, turnip, and radish generally accumulate lower concentrations of pollutant elements than leafy vegetables, such as spinach, methi, menthe, and mint [8]. The use of treated and untreated wastewater for irrigation increased the concentration of $\mathrm{Cd}, \mathrm{Pb}$, and $\mathrm{Ni}$ in the edible portion of vegetables causing a potential health risk in the long term [9]. Thus, irrigation with industrial wastewater has negative impact on leaf area, fresh and dry weight of shoots and roots; the magnitude of decrease was positively correlated with the amount of heavy metals detected in the soil [10]. It was also found that the uptake and accumulation of pollutants vary from plant to plant and also from species to species within a genus [11]. 
Considering the differential impacts of effluents, the present study was designed to determine the effect of different industrial and domestic effluents on the growth, quality, and heavy accumulation of turnip.

\section{MATERIALS AND METHODS}

Eight to ten healthy seeds of turnip were sown in each pot containing $20 \mathrm{~kg}$ of soil incorporated with well-mixed FYM at $20 \mathrm{tha}^{-1}$. The recommended dose of NPK at $75-50-50 \mathrm{~kg} \mathrm{ha}^{-1}$ was applied. After the establishment of plants, these were thinned to four plants pot ${ }^{-1}$. All the effluents from different industries (i.e., ghee mill, sewage water, soap factory, sugar mill, and slaughterhouse wastage) were diluted 10 times before application. These effluents may contain heavy metals and minerals which can affect growth and yield of the plant and may be proven toxic for health. Pots were arranged in a completely randomized design with six treatments replicated four times. The treatments consisted of $\mathrm{T}_{1}$ : Sugar mill effluent, $\mathrm{T}_{2}$ : Sewage water, $\mathrm{T}_{3}$ : Soap factory effluent, $\mathrm{T}_{4}$ : Ghee mill effluent, $\mathrm{T}_{5}$ : Slaughterhouse wastage, and $\mathrm{T}_{6}$ : Control. During plant development, all standard cultural practices were followed. Data on weight of root plant ${ }^{-1}(\mathrm{~g})$, root length $(\mathrm{cm})$, root diameter, yield $\mathrm{ha}^{-1}$, and heavy metals $(\mathrm{Fe}, \mathrm{Pb}, \mathrm{Zn}, \mathrm{Ni}$, and $\mathrm{Cd}$ ) were recorded and statistically analyzed by computing analysis of variance and Least Significant Difference (LSD) by using Microsoft Excel and Statistix-8 computer software package [12].

\section{RESULTS AND DISCUSSION}

\subsection{Growth Characteristics}

\subsubsection{Weight of Root Plant ${ }^{-1}$ (g)}

The root weight plant ${ }^{-1}$ of turnip was significantly $\leq 0.05$ affected by irrigation with different effluents (Table 1). During the 1st year, the significantly higher weight of root plant ${ }^{-1}(80.55 \mathrm{~g})$ was recorded in plants irrigated with sewage water (T2), followed by slaughterhouse wastage (T5) and sugar mill effluent (T1) with root weights of 77.70 and $74.32 \mathrm{~g} \mathrm{plant}^{-1}$, respectively, and all the three treatments varied statistically. The $\mathrm{T} 1$ was also statistically similar to check (T6). The statistically lowest weight of root plant ${ }^{-1}$ $(55.50 \mathrm{~g})$ was found in plants irrigated with ghee mill effluent (T3), succeeded by significantly different soap factory effluent (T4). In the 2nd year, the maximum weight of root plant ${ }^{-1}(82.00$ g) was found in T2 superseded by T5, T1, T6, T4, and T3 and all the treatments differed significantly from each other. During both years, the significantly higher weight of root plant ${ }^{-1}$ than control was registered in order of sewage water, slaughterhouse wastage, and sugar mill effluents, indicating that these effluents contained sufficient plant nutrients to promote plant growth. However, lesser weights of root plant ${ }^{-1}$ than check were recorded in plants receiving ghee mill and soap factory effluents, suggesting that these wastewaters were deficient in plant nutrients. The enhancement in the weight of root plant ${ }^{-1}$ due to sewage water, slaughterhouse wastage, and sugar mill effluent was $10.34 \%$, $6.44 \%$, and $1.81 \%$ during the 1 st year and $12.02 \%, 7.92 \%$, and $2.80 \%$ in the 2 nd year, respectively. Contrarily, ghee mill and soap factory effluents curtailed weight of root plant ${ }^{-1}$ by $23.97 \%$ and $18.87 \%$ in the 1 st year while $22.55 \%$ and $17.35 \%$ in the 2 nd year, respectively. The variation in root weight plant ${ }^{-1}$ indicated that effluents differed in nutrient contents and their efficiency in enhancing root weight of turnip. The wastewaters containing a greater quantity of plant nutrients resulted in greater root weight while wastewaters deficient in nutrients and higher salts resulted in reduced root weight. These results correspond to findings of Damodharan and Reddy [13], who recorded a significant positive correlation between the growth of sugarcane saplings and the nutrient quality of municipal sewage. However, Jadoon et al. [14] and Rehman et al. [15] have recorded the reduction in fresh and dry biomass of root and shoot of turnip, radish, and brassica with un-treated textile waste.

\subsubsection{Root Length (cm)}

Application of different industrial and municipal effluents exerted a significant effect on root length of turnip during both years of study (Table 1). The significantly lengthiest roots $(4.72$ and $4.81 \mathrm{~cm})$ were found in sewage water (T2) irrigated plants during both years. It was preceded by statistically different slaughterhouse wastage (T5) and sugar mill effluent (T1) irrigated plants during the 1st year. The control (T6) was significantly identical to T1. Similarly, soap factory effluent (T4) and ghee mill effluent (T3) were also statistically identical. During the 2nd year, T2 was followed by T5, $\mathrm{T} 1, \mathrm{~T} 6, \mathrm{~T} 4$, and $\mathrm{T} 3$, where all the treatments behaved differently. The plants receiving sewage water, slaughterhouse wastage, and sugar mill effluent increased root length by $18.0 \%, 8.7 \%$, and $2.7 \%$ during the 1 st year, while $18.8 \%, 12.3 \%$, and $2.7 \%$ in the 2 nd year, respectively. The plants irrigated with ghee mill and soap factory effluents showed $40.0 \%$ and $36.2 \%$ reduction in length of root during the 1 st year, while $39.5 \%$ and $35.8 \%$ decrease in the 2 nd year, respectively. The increment in root length reflects

Table 1: Weight of root plant ${ }^{-1}(\mathrm{~g})$, root length $(\mathrm{cm})$, and root diameter $(\mathrm{cm})$ of Turnip as affected by irrigation with different effluents.

\begin{tabular}{lcccccc} 
Effluent/Wastewater & \multicolumn{2}{c}{ Weight of root plant } & \multicolumn{2}{c}{ Length of Root (cm) } & \multicolumn{2}{c}{ Diameter of root (cm) } \\
& 1st Year & 2nd Year & 1st Year & 2nd Year & 1st Year & 2nd Year \\
\hline $\mathrm{T}_{1}$ : Sugar Mill Effluent & $74.32 \mathrm{c}$ & $75.25 \mathrm{c}$ & $4.11 \mathrm{c}$ & $4.16 \mathrm{c}$ & $3.67 \mathrm{a}$ & $3.74 \mathrm{ab}$ \\
$\mathrm{T}$ : Sewage Water & $80.55 \mathrm{a}$ & $82.00 \mathrm{a}$ & $4.72 \mathrm{a}$ & $4.81 \mathrm{a}$ & $3.69 \mathrm{a}$ & $3.83 \mathrm{a}$ \\
$\mathrm{T}_{3}$ : Shee Mill Effluent & $55.50 \mathrm{e}$ & $56.72 \mathrm{f}$ & $2.40 \mathrm{~d}$ & $2.45 \mathrm{f}$ & $1.86 \mathrm{c}$ & $1.90 \mathrm{c}$ \\
$\mathrm{T}_{4}$ : Soap Factory Effluent & $59.22 \mathrm{~d}$ & $60.50 \mathrm{e}$ & $2.55 \mathrm{~d}$ & $2.60 \mathrm{e}$ & $1.95 \mathrm{c}$ & $2.02 \mathrm{c}$ \\
$\mathrm{T}_{5}$ : Slaughterhouse Wastage & $77.70 \mathrm{~b}$ & $79.00 \mathrm{~b}$ & $4.35 \mathrm{~b}$ & $4.55 \mathrm{~b}$ & $3.61 \mathrm{a}$ & $3.68 \mathrm{~b}$ \\
$\mathrm{~T}_{6}$ : Control & $73.00 \mathrm{c}$ & $73.20 \mathrm{~d}$ & $4.00 \mathrm{c}$ & $4.05 \mathrm{~d}$ & $3.45 \mathrm{~b}$ & $3.65 \mathrm{~b}$ \\
LSD $_{0.05}$ & 2.449 & 1.919 & 0.231 & 0.068 & 0.107 & 0.139 \\
\hline
\end{tabular}

Mean followed by similar letter(s) do not differ significantly at $5 \%$ level of significance. 
the positive effect of effluents due to the provision of nutrients while the reduction in length is attributed to the negative effect of wastewater due to greater salts concentration and other growth retarding metals. In accordance with these results, Damodharan and Reddy [13] recorded significant positive, while Rehman et al. [15] reported a negative response on the growth of vegetables.

\subsubsection{Root Diameter $(\mathrm{cm})$}

Root diameter of turnip was significantly influenced by the application of effluents from different sources (Table 1). In the 1st year of trail, the highest root diameter $(3.69 \mathrm{~cm})$ was found in plants irrigated with sewage water (T2) closely followed by sugar mill effluent (T1) and slaughterhouse wastage (T5) with root diameters of 3.67 and $3.61 \mathrm{~cm}$, respectively, and all the three treatments were statistically akin. The lowest root diameter $(1.86 \mathrm{~cm})$ was recorded in plant irrigated with ghee mill effluent (T3) succeeded by soap factory effluent (T4) with $1.95 \mathrm{~cm}$ diameter and both treatments were statistically at par. Control plants possessed roots of intermediate diameter $(3.45 \mathrm{~cm})$ that differed significantly from all other treatments. In the 2 nd year, the maximum root diameter $(3.83 \mathrm{~cm})$ was observed in T2 plants followed by statistically identical T1 $(3.74 \mathrm{~cm})$, which in turn was statistically similar to T5 $(3.68 \mathrm{~cm})$ and T6 $(3.65 \mathrm{~cm})$. The minimum root diameter $(1.90$ $\mathrm{cm})$ was measured in T3 plants succeeded by T4 $(2.02 \mathrm{~cm})$ and both were statistically alike. Application of sewage water, sugar mill effluent, and slaughterhouse wastage resulted in $6.9 \%, 6.4 \%$, and $4.6 \%$ enhancement in root girth during the 1 st year, while in the 2 nd year, the increase was $4.9 \%, 2.5 \%$, and $0.8 \%$, respectively. On the other hand, irrigation with ghee mill and soap factory effluents reduced root diameter by $46.1 \%$ and $43.5 \%$, respectively, during the 1 st year, while $47.9 \%$ and $44.7 \%$ during the 2 nd year, respectively. The greater root diameter resulting from sewage, slaughterhouse, and sugar mill wastewaters may be ascribed to better nutrition while root diameter lesser than control may be related to pollution stress by ghee mill and soap factory effluents [16].

\subsection{Yield $\left(\mathrm{t} \mathrm{ha}^{-1}\right)$}

Significant variation existed in root yield $\left(\mathrm{t} \mathrm{ha}^{-1}\right)$ of turnip due to the application of different effluents (Table 2). During the 1st year, the highest root yield $\left(32.22 \mathrm{t} \mathrm{ha}^{-1}\right)$ was achieved from sewage water (T2) followed by slaughterhouse wastage (T5) and sugar mill effluent (T1). All three treatments varied significantly. However, statistically similar root yields were recorded in T1 and T6 (control). The significantly lowest root yield $\left(22.20 \mathrm{t} \mathrm{ha}^{-1}\right)$ was achieved with ghee mill effluent irrigation (T3) followed by statistically different soap factory effluent (T4) with $23.69 \mathrm{t} \mathrm{ha}^{-1}$ yield. During the 2nd year, the maximum root yield $\left(32.80 \mathrm{t} \mathrm{ha}^{-1}\right)$ was produced from T2 while minimum yield $\left(22.69 \mathrm{t} \mathrm{ha}^{-1}\right)$ was recorded in T3. However, all the treatments varied significantly from each other. During both years, the highest increase in root yield was observed by application of sewage water $(11.2 \%)$, followed by slaughterhouse wastage (7.8\%) and sugar mill effluent $(2.3 \%)$ as compared to control while the highest reduction in root yield was noticed due to irrigation with ghee mill effluent $(23.2 \%)$ followed by soap factory effluent (18.1\%). In accordance with these results, Jadoon et al. [14] documented improved seedling and root lengths of various vegetables with the application of wastewaters at lower concentration but decreased germination and reduced growth was noticed at high concentration of effluents. They found that ghee, textile, and some other industries effluents contain heavy metals that accumulate in vegetables and exert negative impacts on vegetables grown. Rehman et al. [15] reported decreased fresh and dry biomass of root and shoot of turnip with untreated textile wastewater.

\subsection{Heavy Metals}

\subsubsection{Iron $\left(\mathrm{mg} \mathrm{kg}^{-1}\right)$}

Irrigation with different effluents significantly increased the Fe concentration of turnip (Table 3 ). In the 1 st year, the maximum Fe content $\left(2.80 \mathrm{mg} \mathrm{kg}^{-1}\right)$ was found in turnips irrigated with slaughterhouse wastage (T5) that varied significantly from all other treatments. It was followed by significantly different sewage water (T2) and sugar mill effluent (T1), which was also statistically at par with soap factory wastage (T4) that in turn was akin to ghee mill effluent (T3). The minimum Fe content $\left(1.80 \mathrm{mg} \mathrm{kg}^{-1}\right)$ was found in control (T6) that differed significantly from all other effluents. During the 2nd year, the plants from T5 contained the highest Fe concentration $\left(2.82 \mathrm{mg} \mathrm{kg}^{-1}\right)$, superseded by statistically different $\mathrm{T} 2$, T1, and T4 that was also at par with T3. The significantly lowest Fe content $\left(1.81 \mathrm{mg} \mathrm{kg}^{-1}\right)$ was recorded in check plants. During both years, the highest accumulation of Fe (1.55- and 1.56-fold) was observed in plants treated with slaughterhouse wastage (T5), followed by T2, T1, T4, and T3 with 1.44, 1.36, 1.32 , and 1.30 times increase during the 1 st year and $1.47,1.38$, 1.34 , and 1.32 folds increment, respectively, during the 2 nd year. The highest accretion of $\mathrm{Fe}$ in plants receiving slaughterhouse wastage can be attributed to the fact that this wastewater contains the highest quantity of $\mathrm{Fe}$ as compared to other effluents. These results are supported by the findings which indicate the positive relationships between the heavy metal concentration of effluent and plants [17].

\subsubsection{Lead $\left(\mathrm{mg} \mathrm{kg}^{-1}\right)$}

The $\mathrm{Pb}$ content in turnip roots was considerably increased by irrigation with different effluents (Table 3 ). It ranged from 0.06 to 1.05 and 0.06 to $1.10 \mathrm{mg} \mathrm{kg}^{-1}$ in the 1 st and 2 nd year, respectively. During the 1 st year of study, the significantly highest $\mathrm{Pb}$ content (1.05 mg kg-1) was determined in plants treated with sewage water

Table 2: Yield $\left(\mathrm{t} \mathrm{ha}^{-1}\right)$ of Turnip as influenced by irrigation with different effluents.

\begin{tabular}{lcc} 
Effluent/Wastewater & \multicolumn{2}{c}{ Weight of root plant $^{-1}$} \\
& 1st Year & 2nd Year \\
$\mathrm{T}_{1}$ : Sugar Mill Effluent & $74.32 \mathrm{c}$ & $75.25 \mathrm{c}$ \\
$\mathrm{T}_{2}$ : Sewage Water & $80.55 \mathrm{a}$ & $82.00 \mathrm{a}$ \\
$\mathrm{T}_{3}$ : Ghee Mill Effluent & $55.50 \mathrm{e}$ & $56.72 \mathrm{f}$ \\
$\mathrm{T}_{4}$ : Soap Factory Effluent & $59.22 \mathrm{~d}$ & $60.50 \mathrm{e}$ \\
$\mathrm{T}_{5}$ : Slaughterhouse Wastage & $77.70 \mathrm{~b}$ & $79.00 \mathrm{~b}$ \\
$\mathrm{~T}_{6}$ : Control & $73.00 \mathrm{c}$ & $73.20 \mathrm{~d}$ \\
$\mathrm{LSD}_{0.05}$ & 2.449 & 1.919 \\
\hline
\end{tabular}

Mean followed by similar letter(s) do not differ significantly at $5 \%$ level of significance. 
(T2) succeeded by statistically variable sugar mill effluent (T1) and soap factory effluent (T4) that in turn was statistically identical to ghee mill wastage (T3). The lowest $\mathrm{Pb}$ content was recorded in control plants (T6) followed by slaughterhouse wastage (T5) and both treatments contained statistically similar $\mathrm{Pb}$ content. In the 2 nd year, the maximum $\mathrm{Pb}$ content was registered in $\mathrm{T} 2\left(1.10 \mathrm{mg} \mathrm{kg}^{-1}\right)$ followed by T1, T3, and T4 which differed significantly from each other. The minimum $\mathrm{Pb}$ content was determined in $\mathrm{T} 6$ (control) plants preceded by T5 and both were significantly akin. The data revealed that during both years, the maximum accumulation of $\mathrm{Pb}$ (17.50- and 17.92-fold) occurred in plants receiving sewage water followed by sugar mill effluent (15.00 and 16.00 times), soap factory effluent, and ghee mill effluent with 3.33- and 5.00fold increase, each. The lowest enrichment (1.33- and 1.67-fold) was recorded in slaughterhouse wastage treated plants. The data illustrate that the magnitude of increase was positively correlated with the amount of metal in wastewaters. During the 1st year, plants treated with sewage water and sugar mill effluent contained $\mathrm{Pb}$ more than permissible level $\left(0.30 \mathrm{mg} \mathrm{kg}^{-1}\right)$ as recommended by FAO/WHO (2001). During the 2nd year, all samples possessed $\mathrm{Pb}$ above the maximum tolerable limit, except plant irrigated with slaughterhouse wastage and soap factory effluent. $\mathrm{Pb}$ is commonly found in effluents and has no biological importance. It is toxic to plants and also put serious health hazards [18].

\subsubsection{Zinc $\left(\mathrm{mg} \mathrm{kg}^{-1}\right)$}

Application of different effluents significantly elevated the $\mathrm{Zn}$ content of turnip roots (Table-3). During the 1st year, the highest $\mathrm{Zn}$ content $\left(18.00 \mathrm{mg} \mathrm{kg}^{-1}\right)$ was found in plants receiving sewage water (T2) followed by sugar mill effluent (T1), ghee mill effluent
(T3), soap factory effluent (T4), and slaughterhouse wastage (T5) irrigated plants. All treatments differed statistically from each other. In the 2 nd year, the maximum $\mathrm{Zn}$ content $\left(18.50 \mathrm{mg} \mathrm{kg}^{-1}\right)$ was estimated in plants collected from T2, succeeded by T1, T3, and T4 and all four treatments varied significantly. However, T4 and $\mathrm{T} 5$ were statistically identical. In both years, the minimum $\mathrm{Zn}$ contents ( 9.80 and $9.85 \mathrm{mg} \mathrm{kg}^{-1}$ ) were observed in the plant from check pots (T6) that varied significantly from all other treatments. During both years, the highest $\mathrm{Zn}$ enrichment of 1.84 and 1.88 folds was recorded in plants receiving sewage water in the 1st and 2nd year, respectively. Sugar mill, ghee mill, soap factory, and slaughterhouse wastewaters treated plants contained 1.63-, 1.43-, 1.24-, and 1.17-fold $\mathrm{Zn}$ as compared to control, respectively, during the 1 st year, whereas the increase during the 2nd year was 1.68-, 1.47-, 1.27-, and 1.22-fold, respectively. The results showed that $\mathrm{Zn}$ concentration in wastewaters irrigated turnips are within the recommended acceptable maximum range (100.00 $\mathrm{mg} \mathrm{kg}^{-1} \mathrm{Zn}$ ) proposed by the joint FAO/WHO (2001), which are comparable with those available in the literature. Bose and Bhattacharrya [19] reported a significant negative relationship between yield and the concentrations of metals in root and shoot of the wheat plant.

\subsubsection{Nickel ( $\left.\mathrm{mg} \mathrm{kg}^{-1}\right)$}

Different industrial and municipal effluents exhibited a significant effect on $\mathrm{Ni}$ content in turnip roots (Table 4). During both years, a similar sequence was observed regarding $\mathrm{Ni}$ concentration in turnip roots. The highest Ni content $(2.15$ and $2.20 \mathrm{mg} \mathrm{kg}^{-1}$ ) was recorded in plants receiving ghee mill effluent (T3), followed by soap factory effluent (T4) and sugar

Table 3: $\mathrm{Fe}\left(\mathrm{mg} \mathrm{kg}^{-1}\right), \mathrm{Zn}\left(\mathrm{mg} \mathrm{kg}^{-1}\right)$, and $\mathrm{Ni}\left(\mathrm{mg} \mathrm{kg}^{-1}\right)$ concentration in Turnip as affected by irrigation with different effluents.

\begin{tabular}{lcccccc} 
Effluent/ Wastewater & \multicolumn{2}{c}{ Fe $\left(\mathbf{m g ~ k g}^{-1}\right)$} & \multicolumn{2}{c}{$\mathbf{Z n}\left(\mathbf{m g ~ k g}^{-1}\right)$} & \multicolumn{2}{c}{ Ni $\left(\mathbf{m g ~ k g ~}^{-1}\right)$} \\
& 1st Year & 2nd Year & 1st Year & 2nd Year & 1st Year & 2nd Year \\
$\mathrm{T}_{1}$ : Sugar Mill Effluent & $2.45 \mathrm{c}$ & $2.50 \mathrm{c}$ & $16.00 \mathrm{~b}$ & $16.60 \mathrm{~b}$ & $1.55 \mathrm{c}$ & $1.60 \mathrm{c}$ \\
$\mathrm{T}_{2}$ : Sewage Water & $2.60 \mathrm{~b}$ & $2.67 \mathrm{~b}$ & $18.00 \mathrm{a}$ & $18.50 \mathrm{a}$ & $1.50 \mathrm{c}$ & $1.55 \mathrm{c}$ \\
$\mathrm{T}_{3}$ : Ghee Mill Effluent & $2.35 \mathrm{~d}$ & $2.40 \mathrm{~d}$ & $14.00 \mathrm{c}$ & $14.50 \mathrm{c}$ & $2.15 \mathrm{a}$ & $2.20 \mathrm{a}$ \\
$\mathrm{T}_{4}$ : Soap Factory Effluent & $2.37 \mathrm{~cd}$ & $2.42 \mathrm{~d}$ & $12.20 \mathrm{~d}$ & $12.50 \mathrm{~d}$ & $1.70 \mathrm{~b}$ & $1.75 \mathrm{~b}$ \\
$\mathrm{~T}_{5}$ : Slaughterhouse Wastage & $2.80 \mathrm{a}$ & $2.82 \mathrm{a}$ & $11.50 \mathrm{e}$ & $12.00 \mathrm{~d}$ & $1.32 \mathrm{~d}$ & $1.37 \mathrm{~d}$ \\
$\mathrm{~T}_{6}$ : Control & $1.80 \mathrm{e}$ & $1.81 \mathrm{e}$ & $9.80 \mathrm{f}$ & $9.85 \mathrm{e}$ & $1.20 \mathrm{e}$ & $1.22 \mathrm{e}$ \\
LSD $_{0.05}$ & 0.080 & 0.064 & 0.306 & 0.509 & 0.094 & 0.094 \\
\hline
\end{tabular}

Mean followed by similar letter(s) do not differ significantly at $5 \%$ level of significance.

Table 4: $\mathrm{Pb}(\mathrm{mg} \mathrm{kg}-1)$ and $\mathrm{Cd}\left(\mathrm{mg} \mathrm{kg}^{-1}\right)$ of Turnip as affected by irrigation with different effluents.

\begin{tabular}{lcccc} 
Effluent/Wastewater & \multicolumn{2}{c}{ Pb $\left(\mathbf{m g ~ k g}^{-1}\right)$} & \multicolumn{2}{c}{$\mathbf{C d}\left(\mathbf{m g ~ k g}^{-1}\right)$} \\
& 1st Year & 2nd Year & 1st Year & 2nd Year \\
$\mathrm{T}_{1}$ : Sugar Mill Effluent & $0.90 \mathrm{~b}$ & $0.96 \mathrm{~b}$ & $0.050 \mathrm{c}$ & $0.055 \mathrm{c}$ \\
$\mathrm{T}_{2}$ : Sewage Water & $1.05 \mathrm{a}$ & $1.10 \mathrm{a}$ & $0.072 \mathrm{a}$ & $0.075 \mathrm{a}$ \\
$\mathrm{T}_{3}$ : Ghee Mill Effluent & $0.20 \mathrm{c}$ & $0.40 \mathrm{c}$ & $0.047 \mathrm{~cd}$ & $0.050 \mathrm{~d}$ \\
$\mathrm{~T}_{4}$ : Soap Factory Effluent & $0.20 \mathrm{c}$ & $0.30 \mathrm{~d}$ & $0.060 \mathrm{~b}$ & $0.062 \mathrm{~b}$ \\
$\mathrm{~T}_{5}$ : Slaughterhouse Wastage & $0.08 \mathrm{~d}$ & $0.10 \mathrm{e}$ & $0.045 \mathrm{~d}$ & $0.048 \mathrm{~d}$ \\
$\mathrm{~T}_{6}$ : Control & $0.06 \mathrm{~d}$ & $0.06 \mathrm{e}$ & $0.030 \mathrm{e}$ & $0.034 \mathrm{e}$ \\
LSD $_{0.05}$ & 0.079 & 0.046 & 0.004 & 0.003 \\
\hline Mean followed by similar letter(s) do not differ significantly at 5\% level of significant.
\end{tabular}


Ain, et al.: Effect of different effluents on the growth, yield and heavy metal

accumulation of Turnip (Brassica rapa L.) 2019;7(05):35-40

Table 5: Transfer factor (TF) of metals in Turnip with respect to effluents.

\begin{tabular}{lcccccc} 
Metal & Sugar M. effluent & Sewage water & Ghee M. effluent & Soap F. effluent & Slaughterhouse wastage & Metal mean \\
$1 . \mathrm{Fe}$ & 1.37 & 1.46 & 1.32 & 1.33 & 1.56 & 1.41 \\
$2 . \mathrm{Pb}$ & 15.50 & 17.92 & 5.00 & 4.17 & 1.50 & 8.82 \\
$3 . \mathrm{Zn}$ & 1.66 & 1.85 & 1.45 & 1.25 & 1.95 & 1.63 \\
$4 . \mathrm{Ni}$ & 1.29 & 1.25 & 1.79 & 1.42 & 1.10 & 1.37 \\
$5 . \mathrm{Cd}$ & 1.62 & 2.28 & 1.50 & 1.90 & 1.44 & 1.75 \\
Effluent mean & 4.29 & 4.95 & 2.21 & 2.01 & 1.51 & \\
\hline
\end{tabular}

mill effluents (T1) which differed significantly from each other. However, plants from $\mathrm{T} 1$ and $\mathrm{T} 2$ possessed statistically similar Ni content. The significantly lowest Ni content $(1.20$ and $1.22 \mathrm{mg} \mathrm{kg}^{-1}$ ) was found in check plants (T6) superseded by slaughterhouse wastage (T5) treated plants and both treatments were statistically different. During both years, the plants irrigated with ghee mill effluent (T3) accumulated the maximum amount of $\mathrm{Ni}$ viz 1.79 and 1.80 folds in the $1 \mathrm{st}^{\mathrm{t}}$ and 2nd year, respectively. The application of soap factory effluent, sugar mill effluent, sewage water, and slaughterhouse wastage raised Ni content by $1.42,1.29,1.25$, and 1.10 times, respectively, during the 1st year, while the increase was 1.43-, $1.31-, 1.27-$, and 1.12-fold in the 2nd year crop, respectively. These results are in harmony with earlier reports by Ebong et al. [20]. Compared with the permissible limit, the level of Ni in turnip is within the safe limit, which is an indicator that turnip irrigated with these wastewaters is safe for consumption.

\subsubsection{Cadmium $\left(\mathrm{mg} \mathrm{kg}^{-1}\right)$}

Differential response of industrial and municipal effluents was recorded with respect to $\mathrm{Cd}$ content of turnip roots. It varied from 0.030 to 0.072 and 0.034 to $0.075 \mathrm{mg} \mathrm{kg}^{-1}$ during the $1 \mathrm{st}$ and 2 nd year, respectively (Table 4 ). The significantly highest $\mathrm{Cd}$ content was registered in plants irrigated with sewage water (T2), while the lowest concentration was recorded in control plants during both years. In the 1st year, T2 was followed by statistically different T4 $\left(0.060 \mathrm{mg} \mathrm{kg}^{-1}\right)$ and T1 $\left(0.050 \mathrm{mg} \mathrm{kg}^{-1}\right)$ that was significantly at par with T3 $\left(0.047 \mathrm{mg} \mathrm{kg}^{-1}\right)$, which in turn was identical to T5 $\left(0.045 \mathrm{mg} \mathrm{kg}^{-1}\right)$. During the 2nd year, T2 was succeeded by significantly different $\mathrm{T} 4, \mathrm{~T} 1$, and $\mathrm{T} 3$, which was statistically similar to $\mathrm{T} 5$. The statistically lowest $\mathrm{Cd}$ content was observed in control plants. Maximum accretion of $\mathrm{Cd}$ (2.40and 2.21-fold) was observed in sewage water treated plants (T2). It was succeeded by T4, T1, T3, and T5 with 2.00, 1.67, 1.57, and 1.50 times enrichment as compared to control during the 1st year, respectively, while 1.82-, 1.62-, 1.47-, and 1.42-fold increase during the 2 nd year. The plants are widely used as food and natural medicines to treat various ailments; hence, much attention is needed regarding the ways of production to ensure safety [21]. The results indicated that increased heavy metal concentration of effluents resulted in an increased amount of metals in plants. $\mathrm{Cd}$ is phytotoxic, inhibits the growth of plant, and can lead to plant death. Moreover, consumption of this toxic metal can be dangerous to human health [22].

\subsubsection{Relative Accumulation of Heavy Metals}

The results (Table 5) showed that among different metals, the highest transfer factor (8.82) was recorded for $\mathrm{Pb}$, superseded by $\mathrm{Cd}$ (1.75), $\mathrm{Zn}$ (1.63), $\mathrm{Fe}$ (1.41), and $\mathrm{Ni}$ (1.37), indicating the magnitude of TF for heavy metals in order of $\mathrm{Pb}>\mathrm{Cd}>\mathrm{Zn}>$ $\mathrm{Fe}>\mathrm{Ni}$. Regarding effluents, the mean highest TF was registered for sewage water (4.95), followed by sugar mill effluent, ghee mill effluent, soap factory effluent, and slaughterhouse wastage with TF of 4.29, 2.21, 2.01, and 1.51, respectively. These results are in line with the findings reported by Puschenreiter et al. [23] who recorded considerable variations in TF of metals from soil to spinach leaves by reporting TF for $\mathrm{Cd}(5.00), \mathrm{Ni}(0.25), \mathrm{Pb}(0.13)$, and $\mathrm{Zn}$ (1.27). Mahdavian and Somashekar (2008) investigated heavy metals abundance in the vegetables and fruits in the order of $\mathrm{Pb}>\mathrm{Ni}>\mathrm{Zn}>\mathrm{Cd}$ [24], likewise Harati et al. [25,26] recorded concentration of metals in order of $\mathrm{Fe}>\mathrm{Zn}>\mathrm{Pb}>\mathrm{Ni}>\mathrm{Cd}$.

\section{CONCLUSION}

It is deduced from the study that variable impacts of wastewaters were recorded on the growth, yield, and heavy metals accumulation of turnip. Among the effluents, sewage water, slaughterhouse wastage, and sugar mill effluent significantly enhanced the yield and yield attributing traits of turnip, whereas ghee mill and soap factory effluents significantly reduced these parameters. The study suggests that sewage water, slaughterhouse wastage, and sugar mill effluent can be used for raising vegetables for fetching higher yields but ghee mill and soap factory effluents may not be used for irrigation without proper treatment. Heavy metals concentrations, including $\mathrm{Fe}, \mathrm{Pb}, \mathrm{Zn}$, $\mathrm{Ni}$ and $\mathrm{Cd}$ in turnip roots, were significantly increased with all kinds of effluents. The transfer factors showed that the accumulation of metals in turnip roots was in the order of $\mathrm{Pb}>\mathrm{Cd}>\mathrm{Zn}>\mathrm{Fe}>\mathrm{Ni}$.

\section{CONFLICT OF INTEREST}

The authors declare that they have no conflict of interest.

\section{ACKNOWLEDGMENTS}

The authors would like to acknowledge the Department of Food Sciences and Technology, Gomal University DI Khan, Pakistan for kind support and encouragement.

\section{REFERENCES}

1. Romani A, Vignolini P, Isolani L, Ieri F, Heimler D. HPLC-DAD/MS characterization of flavonoids and hydroxycinnamic derivatives in 
turnip tops (Brassica rapa L. subsp. sylvestris L.). J Agric Food Chem 2006;54(4):1342-6.

2. Fernandes F, Valentão P, Sousa C, Pereira JA, Seabra RM, Andrade PB. Chemical and antioxidative assessment of dietary turnip (Brassica rapa var. rapa L.). Food Chem 2007;105(3):1003-10.

3. Toze S. Reuse of effluent water-benefits and risks. Agric Water Manag 2006;80(1-3):147-59.

4. Singh P, Deshbhratar P, Ramteke D. Effects of sewage wastewater irrigation on soil properties, crop yield and environment. Agric Water Manag 2012;103:100-4.

5. Akbar F, Hadi F, Ullah Z, Zia MA. Effect of marble industry effluent on seed germination, post germinative growth and productivity of Zea mays L. Pak J Biol Sci 2007;10:4148-51.

6. Powell W, Morgante M, Andre C, Hanafey M, Vogel J, Tingey S, et al. The comparison of RFLP, RAPD, AFLP and SSR (microsatellite) markers for germplasm analysis. Mol Breed 1996;2(3):225-38.

7. Ale R, Jha P, Belbase N. Effect of distillery effluent on some agricultural crops, a case of environmental injustice to local farmers in Khajura VDC, Banke. Sci World 2008;6(6):68-75.

8. Hundal H, Arora C. Studies on toxic trace elements in vegetables and corresponding soils. Indian J Hortic 1993;50(3):273-8.

9. Sharma R, Agrawal M, Marshall F. Heavy metal contamination in vegetables grown in wastewater irrigated areas of Varanasi, India. Bull Environ Contam Toxicol 2006;77(2):312-8.

10. Ahmed HR, Ahmed HH, Hashem E-DM, Ahmed S. Soil contamination with heavy metals and its effect on growth, yield and physiological responses of vegetable crop plants (Turnip and Lettuce). J Stress Physiol Biochem 2013; 9(4).

11. Singh A, Sharma RK, Agrawal M, Marshall FM. Risk assessment of heavy metal toxicity through contaminated vegetables from waste water irrigated area of Varanasi, India. Trop Ecol 2010;51(2):375-87.

12. Steel R, Torrie J, Dickey D. Principles and procedures of statistics: a biometrical approach. 3rd edition, McGraw-Hill, New York, NY, 1997.

13. Damodharan U, Reddy MV. Impact of sugar industrial treated effluent on the growth factor in sugarcane-Cuddalore, India. J Sustain Bioenergy Syst 2012;2(3):43-8.

14. Jadoon I, Ali S, Jadoon Q, Shakoor M, Bharwana S, Farooq M. Effects of irrigation with waste water from different industries on vegetables grown in vicinity of Faisalabad, Pakistan. Int Res J Plant Sci 2013;4:144-8.

15. Rehman A, Bhatti HN. Textile effluents affected seed germination and early growth of some winter vegetable crops: a case study. Water Air Soil Pollut 2009;198(1-4):155-63.

16. Bhati M, Singh G. Growth and mineral accumulation in Eucalyptus camaldulensis seedlings irrigated with mixed industrial effluents. Bioresour Technol 2003;88(3):221-8.

17. Dheri G, Brar M, Malhi S. Heavy-metal concentration of sewagecontaminated water and its impact on underground water, soil, and crop plants in alluvial soils of northwestern India. Commun Soil Sci Plant Anal 2007;38(9-10): 1353-70.

18. Xiong Z-T. Lead uptake and effects on seed germination and plant growth in a $\mathrm{Pb}$ hyperaccumulator Brassica pekinensis Rupr. Bull Environ Contam Toxicol 1998;60(2):285-91.

19. Bose S, Bhattacharyya A. Heavy metal accumulation in wheat plant grown in soil amended with industrial sludge. Chemosphere 2008;70(7):1264-72.

20. Ebong G, Etuk H, Johnson A. Heavy metals accumulation by Talinum triangulare grown on waste dumpsites in Uyo metropolis, Akwa Ibom State, Nigeria. J Appl Sci 2007;7(10):1404-9.

21. Tanveer S, Latif A, Ashiq K, Qayyum M, Bajwa MA. A comprhensive review on pharmacological and phytochemical potential of Cassia Fistula Linn: A magical herb. Int J Biol Pharm Allied Sci 2019;8(6):1134-57.

22. Sandalio L, Dalurzo H, Gomez M, Romero-Puertas M, Del Rio L. Cadmium-induced changes in the growth and oxidative metabolism of pea plants. J Exp Bot 2001;52(364):2115-26.

23. Puschenreiter M, Horak O, Friesl W, Hartl W. Low-cost agricultural measures to reduce heavy metal transfer into the food chain-a review. Plant Soil Environ 2005;51(1):1-11.

24. Mahdavian SE, Somashekar R. Heavy metals and safety of fresh fruits in Bangalore city, India-A case study. Kathmandu Univ J Sci Eng Technol 2008;4(1):17-27.

25. Harati M. Study on heavy metal accumulation in different parts of corn irrigated by sewage in south of Tehran. Msc Thesis, Tehran University, 2003.

26. Harati M, Rastegar MT, Foghi B. Effect of urban wastewater usage and problems of accumulation of heavy metals in agricultural lands (south of Tehran). Afr J Agric Res 2011;6(14):3224-31.
How to cite this article:

Ain NU, Ain QU, Javeria S, Ashiq S, Ashiq K, Akhtar MS. Effect of different industrial and domestic effluents on growth, yield, and heavy metal accumulation in Turnip (Brassica rapa L.). J Appl Biol Biotech 2019;7(05):35-40. 